\title{
KONTRIBUSI FASILITAS DAN DISIPLIN BELAJAR TERHADAP HASIL BELAJAR SISWA DALAM PEMBELAJARAN IPS
}

\author{
Lili Dianah \\ Guru SMP Negeri 3 Lembang Bandung Barat \\ lilidianah@gmail.com
}

\begin{abstract}
The research was based on the low value of social studies learning in Public Junior High School in West Bandung regency. The average value of KKM (Minimum Achievement Criteria), that was 66.08 which was still below the value set by LPMP (Education Quality Assurance Institution) that was at least 75 . The research was conducted to find out the contribution of facility and learning discipline toward student learning result in social studies learning. This research used quantitative approach and Survey method (explanatory research). Analysis of learning result throughed average of student test results, and analysis of dicipline and learning facilities used questionnaire. The population students were 4231 students from 13 schools that classified SSN (National School Standar) in West Bandung regency. For research samples, there were 256 students from 7 schools. The sampling used Stratified Random Sampling. The results showed that learning facilities contributed to student learning result was 0.191 or $3.6 \%$. The discipline of learning contributed to student learning outcomes was 0.353 or $12.5 \%$. From the results of the study could be concluded that the facilities and discipline of student learning had a significant contribution to student learning result. Therefore the completeness of the facilities and the level of discipline students had to be improved and got attention more.
\end{abstract}

Keyword: facilities, learning dicipline, student learning result

Abstrak. Penelitian ini dilatar belakangi oleh rendahnya nilai pembelajaran IPS di SMP Negeri di Kabupaten Bandung Barat. Nilai rata-rata KKM (Kriteria Ketuntasan Minimum) adalah 66,08, masih jauh nilai KKM yang ditetapkan LPMP (Lembaga Penjamin Mutu Pendidikan) yaitu minimal 75. Penelitian ini dilakukan untuk mengetahui seberapa besar kontribusi fasilitas dan disiplin belajar terhadap hasil belajar siswa dalam pembelajaran IPS. Penelitian ini menggunakan pendekatan kuantitatif dan metode Survai (explanatory research). Analisis hasil belajar dilakukan melalui rata-rata hasil ulangan siswa. Sedangkan analisis disiplin dan fasilitas belajar dilakukan dengan menggunakan kuesioner yang terlebih dahulu melakukan proses uji validitas dan reliabilitas. Populasi siswa di SMP Negeri yang berklasifikasi SSN di Kabupaten Bandung Barat berjumlah 4231 siswa dari 13 sekolah, sedangkan penarikan sampel siswa dilakukan dengan cara Stratified Random Sampling dan sejumlah 7 sekolah yang menjadi sampel penelitian, dengan 256 siswa yang diambil untuk dijadikan objek penelitian. Hasil penelitian menunjukkan bahwa fasilitas belajar berkontribusi terhadap hasil belajar siswa sebesar 0,191 atau 3,6 \%. Disiplin belajar berkontribusi terhadap hasil belajar siswa sebesar 0,353 atau 12,5\%. Dari hasil penelitian dapat disimpulkan bahwa fasilitas dan disiplin belajar siswa memiliki kontribusi yang signifikan terhadap hasil belajar siswa. Oleh karena itu kelengkapan fasilitas dan tingkat disiplin siswa perlu ditingkatkan serta perlu mendapat perhatian dari berbagai pihak. 
Kata kunci: fasilitas, disiplin belajar, hasil belajar siswa

\section{PENDAHULUAN}

Berbicara tentang mutu pendidikan tidak akan lepas dari kegiatan belajar. Menurut Cronbach (1954 dalam Sumardi Suryabrata, 2010:231) menyatakan bahwa; “ belajar sebagai suatu aktivitas yang ditunjukkan oleh perubahan tingkah laku sebagai hasil dari pengalaman". Senada dengan pendapat Cronbach, menurut Gagne (1977 dalam Sumardi Suryabrata, 2010:231), bahwa "belajar adalah suatu perubahan perilaku yang relatif menetap yang dihasilkan dari pengalaman masa lalu ataupun dari pembelajaran yang bertujuan atau direncanakan". Jadi belajar adalah sebuah proses yang kompleks yang didalamnya terkandung beberapa aspek, yaitu: bertambahnya jumlah pengetahuan, adanya kemampuan mengingat, ada penerapan pengetahuan, menyimpulkan makna, menafsirkan dan mengaitkannya dengan realitas dan adanya perubahan sebagai pribadi.

Kegiatan belajar yang diharapkan adalah hasil belajar yang baik. Memperoleh hasil belajar yang baik tidaklah mudah, banyak faktor yang mempengaruhi. Nasution (1993 Syaiful Bahri, 2008:175) dalam memandang bahwa. "belajar itu bukanlah suatu aktivitas yang berdiri sendiri, melainkan ada unsur-unsur lain yang ikut terlibat langsung di dalamnya, yaitu raw input, learning teaching process, output, inviromental input, dan instrumental input. Masukan mentah (raw input) merupakan bahan pengalaman belajar tertentu dalam proses belajar mengajar (learning teaching process) dengan harapan dapat berubah menjadi keluaran (output) dengan kualifikasi tertentu. Di dalam proses belajar mengajar itu ikut berpengaruh sejumlah faktor lingkungan, yang merupakan masukan dari lingkungan (environmental input) dan sejumlah faktor instrumental (instrumental input) yang dengan sengaja dirancang dan dimanipulasikan guna menunjang tercapainya keluaran yang dikehendaki.

Untuk mengetahui hasil belajar siswa, perlu diadakan evaluasi . Menurut Eveline Siregar (2010 : 142), bahwa "evaluasi pembelajarana adalah suatu proses menentukan nilai prestasi belajar pembelajaran dengan menggunakan patokan-patokan tertentu agar mencapai tujuan pengajaran yang telah ditentukan". Selain itu, berdasarkan UU Sisdiknas No. 20 Tahun 2003 Pasal 58 (1) "evaluasi hasil belajar peserta didik dilakukan untuk memantau proses, kemajuan, dan perbaikan hasil belajar peserta didik secara berkesinambungan". Oleh karena itu, maka evaluasi belajar seyogyanya dilakukan guru secara terus menerus dengan berbagai cara, bukan hanya pada saat-saat ulangan terjadwal atau saat ujian belaka.

Dalam konteks proses belajar, gejala negative yang tampak adalah kurangnya kemandiri an dalam belajar yang berakibat pada gangguan mental setelah memasuki perguruan tinggi (Soewandi, 1993:186), kebiasaan belajar yang kurang baik yaitu tidak tahan lama, baru belajar setelah menjelang ujian, membolos, menyontek dan mencari bocoran soal ujian (Engkoswara, 1987:2). Dengan problematika tersebut maka usaha pendidikan yang dilakukan secara sungguh-sungguh untuk mengembangkan kemandirian belajar menjadi sangat penting agar mendapatkan hasil belajar yang baik.

Hasil pra penelitian di lapangan ditemukan bahwa hasil belajar dalam pembelajaran IPS kelas 8 di SMP Negeri yang berklasifikasi SSN di Kabupaten Bandung Barat masih sangat rendah. Nilai rata-rata KKM dalam pembelajaran IPS 
kelas 8 di SMP Negeri yang berklasifikasi SSN di Kabupaten Bandung Barat hanya mencapai 66,08. Sedangkan LPMP (Lembaga Penjaminan Mutu Pendidikan) mengharapkan nilai rata-rata $\mathrm{KKM}$ serendah-rendahnya 75 .

Perilaku disiplin sangat diperlukan dalam pembinaan perkembangan anak untuk menuju masa depan yang lebih baik. Disiplin dapat melahirkan semangat menghargai waktu, Orang-orang yang berhasil dalam belajar dan berkarya disebabkan mereka selalu menempatkan disiplin di atas semua tindakan dan perbuatan. Semua jadwal pelajaran yang telah disusun mereka taati dengan ikhlas. Mereka melaksanakannya dengan penuh semangat. Rela mengorbankan apa saja demi perjuangan menegakkan disiplin pribadi.

Untuk menanamkan kedisiplinan siswa harus dimulai dari dalam diri kita sendiri, barulah kita dapat mendisiplinkan orang lain sehingga akan tercipta ketenangan, ketentraman, dan keharmonisan. Disiplin belajar dapat melahirkan hal-hal seperti; dapat menepati jadwal belajar di sekolah dan di rumah yang dibuat sendiri, dapat mengatasi godaan yang akan menunda waktu belajar, dapat menjaga kondisi fisik sebagai persiapan belajar, dapat disiplin terhadap diri, dapat menyelesaikan tugas pada waktunya, dapat belajar dengan menyicil, dapat menunjukkan sikap antusias dalam belajar, tidak melakukan hal-hal yang dilarang guru dan dapat belajar secara kontinyu.

Selain disiplin belajar, hasil belajar juga dipengaruhi oleh fasilitas belajar. Menurut Syaiful Bahri (2002: 40), "siapapun sependapat bahwa fasilitas belajar ikut menentukan keberhasilan belajar seseorang". Dalam penelitian terdahulu; Heru Cahyono (2009) dan Krismanto (2007), melaporkan temuannya yang serupa bahwa fasilitas belajar dengan prestasi siswa memiliki hubungan yang positif dan signifikan. Orang yang belajar tanpa dibantu dengan fasilitas tidak jarang mendapatkan hambatan dalam menyelesaikan kegiatan belajar. Karenanya, fasilitas tidak bisa diabaikan dalam masalah belajar. Fasilitas belajar merupakan salah satu faktor eksternal untuk mendukung hasil belajar siswa di sekolah. Menurut Suharsimi Arikunto (1997:6); "fasilitas adalah segala sesuatu yang dapat memudahkan dan melancarkan pelaksanaan sesuatu usaha".

Fasilitas belajar sangat penting dalam proses pembelajaran untuk mendukung kegiatan pengajaran dan juga dapat menumbuhkan minat dan perhatian dari siswa untuk mempermudah penyampaian materi pembelajaran. Kegiatan belajar mengajar memerlukan adanya fasilitas agar kegiatan tersebut berjalan dengan lancar dan teratur. Pemenuhan fasilitas belajar yang baik dapat mendorong siswa untuk rajin belajar. Fasilitas belajar yang dimiliki siswa yang dapat memudahkan dan melancarkan pelaksanaan belajar berupa buku paket yang dimiliki siswa, buku catatan, alat tulis, meja dan kursi belajar, ruang tempat belajar, penerangan cukup computer dan sebagainya. Semua fasilitas belajar di atas akan sangat membantu peserta didik dalam belajar. Paling tidak akan memperkecil kesulitan belajar.

Berdasarkan latar belakang tersebut maka peneliti tertarik untuk mengambil judul "Kontribusi Fasilitas dan Disiplin Belajar terhadap Hasil Belajar Siswa dalam Pembelajaran IPS di SMP Negeri Kabupaten Bandung Barat.

\section{METODE}

Penelitian ini menggunakan pendekatan kuantitatif, karena data penelitian berupa angka-angka dan analisisnya menggunakan statistik. 
Penelitian ini menggunakan metode Survai (explanatory research) yaitu menjelaskan hubungan kausal dan pengujian hipotesis. Menurut Masri Singarimbun (2008:3), "Penelitian Survai adalah penelitian yang mengambil sampel dari satu populasi dan menggunakan koesioner sebagai pengumpul data yang pokok".

Populasi dalam penelitian ini adalah SMP Negeri se-Kabupaten Bandung Barat yang termasuk ke dalam klasifikasi SSN (Sekolah Standar Nasional). SSN adalah sekolah yang sudah atau hampir memenuhi Standar Nasional Pendidikan. Jumlah sekolah yang menjadi populasi adalah 13 Sekolah SSN, yang terdiri dari 4231 siswa kelas 8. Teknik penentuan sampel dalam penelitian ini dengan menggunakan Stratified Random Sampling yaitu cara pengambilan sampel dari anggota populasi secara acak dan berstrata.

Dalam penelitian ini jumlah SMP SSN yang dijadikan sampel sebanyak 7 sekolah dengan jumlah siswa 2384 orang, yaitu : SMPN 1 Cihampelas, SMPN 1 Cililin, SMPN 1 Padalarang, SMPN 2 Batujajar, SMPN 2 Ngamprah, SMPN 3 Lembang, SMPN 1 Lembang. Sampel dalam penelitian ini terdiri dari 256 siswa.

Instrument penelitian ini menggunakan kuesioner. Kuesioner digunakan untuk mengukur fasilitas dan disiplin belajar. Data kuesioner diuji dengan uji validitas (test of validity) dan uji reliabilitas (test of reliability) guna menguji ke akuratan dan kesungguhan dari jawaban responden. Uji validitas dan uji reliabilitas akan dilakukan terhadap item-item pertanyaan yang disusun berdasarkan skala likert. Sedangkan hasil pembelajaran IPS akan diukur dengan menggunakan hasil ratarata nilai ulangan harian siswa kelas 8 .

Berdasarkan masalah penelitian dan operasionalisasi variabel yang diteliti dan hipotesis penelitian yang diajukan, maka uji statistik yang digunakan adalah regresi ganda (dua variabel) dan uji korelasi Product Moment.

\section{HASIL PEMBAHASAN}

Berikut ini disajikan data hasil analisa terhadap fasilitas belajar (X1), disiplin belajar (X2) dan hasil belajar (Y), dari responden yang menjadi sampel penelitian sebanyak 256 siswa yang berasal dari SMP Negeri yang berklasifikasi SSN di Kabupaten Bandung Barat.

Menurut Saifudin Azwar (1999:109): untuk mengelompokkan jumlah item soal setiap variabel pada skala sikap, dapat menggunakan:

$$
\begin{array}{lr}
X<(\mu-1,0 \sigma) & \text { rendah } \\
(\mu-1,0 \sigma) \leq X<(\mu+1,0 \sigma) & \text { sedang } \\
(\mu+1,0 \sigma) \leq X & \text { tinggi }
\end{array}
$$

\section{a) Fasilitas Belajar}

Data fasilitas belajar terdiri dari 8 item, rentang minimum-maksimumnya adalah : $8 \times 1=8$ sampai dengan $8 \times 5=40$, sehingga luas jarak sebarannya adalah $40-8=32$, Dengan demikian setiap satuan deviasi standarnya bernilai $\sigma=32 / 6=5$, dan mean teoritisnya adalah $\mu=8 \times 3=24$.

$$
\begin{aligned}
X_{1}<19 & \text { rendah } \\
19 \leq X_{1}<29 & \text { sedang } \\
29 \leq X_{1} & \text { Tinggi }
\end{aligned}
$$

Skor rendah dan sedang dimasukan ke dalam kategori kurang lengkap, sedangkan skor tinggi dimasukan ke dalam kategori lengkap. Dapat dilihat pada tabel dibawah ini:

Data Fasilitas Belajar

\begin{tabular}{|l|c|c|}
\hline Uraian & Frekuensi & Prosentase \\
\hline Lengkap & 95 & $37,11 \%$ \\
\hline $\begin{array}{l}\text { Kurang } \\
\text { lengkap }\end{array}$ & 161 & $62,89 \%$ \\
\hline Jumlah & $\mathbf{2 5 6}$ & $\mathbf{1 0 0} \%$ \\
\hline
\end{tabular}

Data di atas menunjukkan bahwa kelengkapan fasilitas belajar dari sekolah 
yang menjadi sampel, termasuk kedalam kategori kurang lengkap.

\section{b) Disiplin Belajar}

Data disiplin belajar terdiri dari 16 item, rentang minimum-maksimumnya adalah :

$16 \times 1=16$ sampai dengan $16 \times 5=80$, sehingga luas jarak sebarannya adalah

$80-16=64$, Dengan demikian setiap satuan deviasi standarnya bernilai $\sigma=64 / 6$ $=10$, dan mean teoritisnya adalah $\mu=16 \mathrm{x}$ $3=48$.

$$
\begin{array}{rc}
\mathrm{X}_{2}<38 & \text { rendah } \\
38 \leq \mathrm{X}_{2}<58 & \text { sedang } \\
58 \leq \mathrm{X}_{2} & \text { tinggi }
\end{array}
$$

Data Disiplin Belajar

\begin{tabular}{|c|c|c|}
\hline Uraian & Frekuensi & Prosentase \\
\hline Tinggi & 42 & $16,41 \%$ \\
\hline Sedang & 212 & $82,81 \%$ \\
\hline Rendah & 2 & $0,78 \%$ \\
\hline Jumlah & $\mathbf{2 5 6}$ & $\mathbf{1 0 0} \%$ \\
\hline
\end{tabular}

Data di atas menunjukkan bahwa tingkat disiplin belajar dari sekolah yang menjadi sampel, termasuk kedalam kategori sedang.

\section{c) Hasil Belajar Siswa}

Berdasarkan Permendiknas No 41 tahun 2007 tentang Standar Proses, LPMP menetapkan bahwa "Indikator yang harus dicapai dalam pembelajaran adalah $75 \%$, sehingga KKM (Kriteria Ketuntasan Minimum) yang ditetapkan oleh LPMP (Lembaga Penjamin Mutu Pendidikan) untuk SMP Negeri yang berklasifikasi SSN, pada mata pelajaran IPS minimal memiliki nilai KKM 75, maka nilai dikategorikan tinggi $(Y \geq 90)$, sedang (75 $\leq$ $\mathrm{Y}<90)$, rendah $(\mathrm{Y}<75)$. Data penelitian hasil belajar siswa dideskripsikan sebagai berikut.
Data Hasil Belajar Siswa Pada Mata Pelajaran IPS

\begin{tabular}{|c|c|c|}
\hline Uraian & Frekuensi & Prosentase \\
\hline Tinggi & 31 & $12,11 \%$ \\
\hline Sedang & 84 & $32,81 \%$ \\
\hline Rendah & 141 & $55,08 \%$ \\
\hline Jumlah & $\mathbf{2 5 6}$ & $\mathbf{1 0 0} \%$ \\
\hline
\end{tabular}

Dari tabel di atas menunjukkan bahwa hasil belajar siswa di sekolah yang menjadi sampel, termasuk kedalam kategori rendah.

\section{Kontribusi Fasilitas Belajar terhadap Hasil Belajar Siswa}

Dari hasil uji hipotesis menunjukkan bahwa fasilitas belajar berpengaruh secara positif dan signifikan terhadap hasil belajar siswa. Menurut Saeful Bahri (2002: 40) "fasilitas dan perabot belajar ikut menentukan keberhasilan belajar seseorang". Menurut The Liang Gie (2002: 46), bahwa "untuk mendapatkan hasil belajar yang baik hendaknya tersedia fasilitas belajar yang memadai, antara lain ruang tempat belajar, penerangan cukup, buku-buku pegangan, dan kelengkapan peralatan komputer". Fasilitas belajar merupakan faktor dari luar yang dapat mempengaruhi hasil belajar. Siswa yang belajar tanpa dibantu dengan fasilitas belajar tidak jarang mendapatkan hambatan baik dalam belajar maupun dalam menyelesaikan tugas-tugasnya yang diberikan oleh guru.

Dari hasil penelitian menunjukkan bahwa hasil belajar siswa dapat dipengaruhi oleh fasilitas belajar sebesar 0,191 atau 3,6 \%. Hal ini dapat diterima karena fasilitas belajar yang diteliti dalam penelitian ini hanya mencakup kelengkapan belajar yang tersedia atau yang dimiliki siswa, meliputi; tersedia buku paket/pegangan, memiliki alat tulis, tersedia meja dan kursi belajar, tersedia komputer, tersedia ruang belajar dan tersedia penerangan yang cukup. Banyak 
faktor lain di luar penelitian ini yang ikut mempengaruhi hasil belajar siswa.

Fasilitas belajar yang mencakup buku paket/pegangan, ruang belajar, meja dan kursi belajar, komputer, perlengkapan belajar dan penerangan yang cukup akan sangat membantu siswa dalam belajar. Paling tidak akan memperkecil kesulitan belajar. Hal ini terbukti dalam penelitian ini. Kelengkapan fasilitas belajar yang dimiliki siswa, masuk dalam kategori kurang lengkap. Dari 256 siswa, 141 siswa atau 55,08 \% memiliki hasil belajar dibawah KKM (kategori rendah). Hal ini didukung hasil penelitian yang menunjukkan bahwa fasilitas belajar berkontribusi terhadap fasilitas belajar sebesar 3,6 \% (kategori rendah).

Kendala yang dihadapi siswa dalam memenuhi kelengkapan fasilitas belajar, yang ditemukan dalam penelitian adalah siswa tidak memiliki perlengkapan belajar dan tidak tersedianya komputer. Perlengkapan belajar yang standar seperti; bolpoint, penggaris, penghapus, serutan, pensil, dll, sering dianggap tidak terlalu penting sehingga siswa saling meminjam dan akhirnya perlengkapan belajar tidak terpenuhi. Komputer adalah salah satu fasilitas belajar yang cukup mahal. Tidak semua siswa berasal dari keluarga kaya, sehingga tidak mungkin memaksakan diri untuk memenuhi semua fasilitas belajar. Mereka yang berasal dari keluarga sederhana tentu saja harus pandai menentukan mana fasilitas yang harus dipenuhi.

Fasilitas sangat penting dan berpengaruh terhadap hasil belajar, oleh karena itu pihak sekolah harus membantu menyediakan fasilitas belajar yang memadai. Diharapkan setiap sekolah memiliki laboratorium komputer untuk membantu para siswa yang tidak memiliki fasilitas komputer di rumah. Para orang tua hendaknya menyediakan kelengkapan belajar dan mengingatkan putra putrinya untuk memelihara kelengkapan belajar tersebut.

\section{Kontribusi Disiplin Belajar Terhadap Hasil Belajar Siswa}

Dari hasil uji hipotesis menunjukkan bahwa disiplin belajar berpengaruh secara positif dan signifikan terhadap hasil belajar siswa. Menurut Saeful Bahri (2008 : 15), "salah satu yang mengantarkan siswa berhasil dalam belajar adalah disiplin ". Senada dengan pendapat Saeful Bahri, Tu'u Tulus (2004:37) mengatakan bahwa "Disiplin merupakan jalan bagi siswa untuk sukses dalam belajar dan pada saat masuk dalam dunia kerja. Kesadaran pentingnya norma, aturan, kepatuhan dan ketaatan merupakan prasyarat kesuksesan seseorang".

Disiplin yang baik adalah disiplin yang berawal dari diri sendiri, sebab penegakan disiplin yang berawal dari diri sendiri, berarti disiplin itu timbul atas kesadaran sendiri. Hal ini sesuai dengan pendapat Sulistiyowati (2001:3), "agar seorang siswa dapat belajar dengan baik maka ia harus bersikap disiplin, terutama dalam hal: disiplin dalam menepati jadwal pelajaran, disiplin dalam mengatasi godaan yang akan menunda waktu belajar, disiplin terhadap terhadap diri dan disiplin dalam menjaga kondisi fisik". Individu yang memiliki kedisiplinan belajar di rumah akan menunjukkan ciri sebagai berikut: memiliki waktu belajar yang teratur, belajar dengan menyicil (sedikit demi sedikit), menyelesaikan tugas pada waktunya, belajar dalam suasana yang mendukung.

Dari hasil penelitian menunjukkan bahwa disiplin belajar berkontribusi terhadap hasil belajar siswa sebesar 0,353 atau $12,3 \%$. Hal ini dapat diterima, karena banyak faktor lain di luar penelitian ini yang dapat mempengaruhi hasil belajar siswa. Disiplin belajar dalam penelitian ini mencakup: menepati jadwal belajar di sekolah dan di rumah yang dibuat sendiri, 
mengatasi godaan yang akan menunda waktu belajar, persiapan belajar(menjaga kondisi fisik), disiplin terhadap diri, menyelesaikan tugas pada waktunya, belajar dengan menyicil, menunjukkan sikap antusias dalam belajar, tidak melakukan hal-hal yang dilarang guru dan belajar secara kontinyu.

Siswa yang memiliki disiplin belajar yang tinggi akan dapat belajar dengan baik, terarah dan teratur sehingga dimungkinkan akan mendapat hasil belajar yang baik pula. Hal ini terbukti dalam penelitian ini. Tingkat disiplin belajar di sekolah yang menjadi sampel, berada dalam kategori sedang . Dari 256 siswa, 141 siswa atau 55,08 \% memiliki nilai rendah atau dibawah KKM. Karenanya disiplin belajar tidak bisa diabaikan karena akan mempengaruhi hasil belajar. Dengan disiplin belajar, siswa akan mampu mengkondisikan dirinya untuk belajar dan dengan kedisiplinan memungkinkan siswa untuk mencapai hasil belajar yang memuaskan sesuai dengan harapan masyarakat.

Kendala yang dihadapi dalam disiplin belajar, diantaranya adalah: Pertama melakukan hal-hal yang dilarang guru yaitu mencontek pada saat ulangan. Kedua, mengatasi godaan yang akan menunda waktu belajar yaitu godaan mematikan HP saat belajar dan godaan bermain dengan teman sebelum belajar.

Berhubung disiplin belajar sangat penting dan berpengaruh terhadap hasil belajar, maka pihak sekolah khususnya para guru dan para orang tua hendaknya sama-sama menanamkan kejujuran, mendorong siswa untuk percaya diri dan memberikan motivasi untuk belajar lebih giat dan teratur agar pada saat ulangan siswa merasa siap dan tidak mencontek. Menurut Saeful Bahri (2008:15), “kunci sukses belajar adalah belajar dengan teratur,disiplin dan bersemangat, konsentrasi, pengaturan waktu, istirahat dan tidur".

Siswa harus diberikan motivasi oleh berbagai pihak, baik guru, orang tua maupun oleh lingkungan sekitarnya, sehingga disiplin belajar yang muncul adalah disiplin dari kesadaran, bukan paksaan. Menurut Syaiful Bahri (2008:17), "disiplin yang muncul karena kesadaran disebabkan seseorang menyadari bahwa hanya dengan disiplinlah akan didapatkan kesuksesan dalam segala hal, dengan disiplinlah didapat keteraturan dalam kehidupan, dengan disiplinlah dapat menghilangkan kekecewaan orang lain dan dengan disiplinlah orang lain mengaguminya". Jadi dalam belajar sangat diperlukan disiplin . Orang yang berhasil dalam belajar dan berkarya disebabkan mereka selalu menempatkan disiplin diatas semua tindakan dan perbuatan.

Siswa perlu dibantu untuk mengatasi godaan yang akan menunda waktu belajar, yaitu dengan cara: pertama, guru melarang siswa untuk mengaktifkan HP disaat proses belajar mengajar berlangsung dan orang tua terus mengingatkan putra-putrinya untuk mematikan HP pada saat akan belajar, dengan demikian siswa akan mendapatkan konsentrasi dalam belajar. Orang yang tidak dapat berkonsentrasi, pasti tidak akan berhasil menyimpan atau menguasai bahan pelajaran, karena itu siswa harus berusaha untuk mempertahankan konsentrasinya dalam belajar. Ada hal-hal lain yang ikut mempengaruhi lama pendeknya daya konsentrasi seseorang ketika sedang belajar. Menurut Abu Ahmadi (1991) dalam Syaiful Bahri (2008: 21), mengemukakan sebab-sebab seseorang tidak dapat berkonsentrasi, antara lain:

1) Kurang minat terhadap mata pelajaran, mengakibatkan seseorang sukar 
mengerti isi pelajaran. Akhirnya pekiran melayang-layang pada hal lain.

2) Banyak urusan yang sering mengganggu perhatian, baik urusan luar maupun urusan pribadi.

3) Adanya gangguan-gangguan suara keras seperti radio, tape, TV, udara yang sangat panas,meja berantakan dan sebagainya.

4) Adanya gangguan kesehatan atau terlalu lelah.

Masih menurut Abu Ahmadi (1991), untuk mengatasi agar seseorang dapat mengembangkan kemampuan konsentrasinya yaitu:

1) Harus berminat terhadap mata pelajaran.

2) Harus mempunyai ruang khusus untuk belajar.

3) Meja belajar hendaknya bersih dari segala benda yang tidak bersangkut paut dengan mata pelajaran yang sedang dipelajaari.

4) Mampu menghilangkan urusanurusan kecil yang selalu mengganggu pikiran sehingga pikiran terbebas dari keteganganketegangan kecil yang selalu mengganggu.

5) Alat tulis dan kertas merupakan alat yang sangat berguna untuk membantu menciptakan konsentrasi. Bagian-bagian penting dalam buku dapat digaris bawahi.

6) Istirahat sebentar jika merasa jemu dan letih belajar agar pikiran jernih kembali.

7) Usahakan agar badan selalu sehat.

Dari 256 siswa, 141 siswa atau 55,08 \% memiliki hasil belajar dibawah KKM (kategori rendah). Guru memiliki peranan penting dalam meningkatkan hasil belajar siswa. Prestasi yang rendah tentunya dipengaruhi pula oleh kondisi pembelajaran yang masih bersifat konvensional dan tidak menyentuh ranah dimensi peserta didik itu sendiri. Dalam arti yang lebih subtansial, bahwa proses pembelajaran dewasa ini masih memberikan dominasi guru dan tidak memberikan akses bagi anak didik untuk berkembang secara mandiri melalui penemuan dan proses berpikirnya. Dari kelemahan-kelemahan yang dimiliki oleh guru-guru IPS, dapat pula mempengaruhi hasil belajar. Guru IPS pada umumnya melakukan evaluasi hanya menekankan pada aspek tujuan, tidak pada proses pembelajaran.

Menurut Suwarma Al Muchtar (2008:132), sikap dan kinerja guru yang perlu dilakukan dalam meningkatkan mutu pembelajaran IPS adalah;

a. Guru sebagai pendidik yang memiliki kepekaan dan kemampuan untuk mengembangkan potensi intelektual, emosional dan sosial peserta didik.

b. Guru IPS memiliki kemampuan untuk menciptakan situasi pembelajaran yang memungkinkan terjadinya proses belajar.

c. Guru IPS memiliki kemampuan dalam pengelolaan kelas untuk terjadinya proses belajar dan pengalaman pembelajaran yang kuat.

d. Guru IPS mampu bertindak sebagai ilmuwan pendidik yang dapat mengembangkan semangat berpikir ilmiah pembelajaran peserta didik.

e. Guru IPS sebagai panutan terutama dalam pembangunan nilai-nilai.

f. Guru IPS sebagai motivator sehingga tumbuh semangat ingin belajar

Masih menurut Suwarma Al Muchtar (2008:46) bahwa, faktor yang dapat meningkatkan hasil belajar siswa pada mata pelajaran IPS adalah;

1) Guru berani bertindak sebagai pengembang program, untuk memasukan bahan-bahan yang 
bersumber dari kehidupan sosial budaya lingkungan peserta didik .

2) Adanya peningkatan kesejahteraan guru, perlu diciptakan iklim kerja produktif, dengan memerankan dan menghargai guru sebagai sumberdaya manusia pendidik.

3) Sistim evaluasi lebih fungsional apabila lebih menekankan pada aspek proses strategi pembelajaran dari pada tujuan.

4) Mengembangkan muatan lokal secara terintegrasi, untuk memberikan nilai tambah bagi fungsionalisasi materi strategi pembelajaran IPS.

5) Adanya peningkatan mutu buku baik buku pedoman guru maupun buku pegangan siswa.

Jadi untuk meningkatkan hasil belajar, guru memiliki peran penting disamping fasilitas dan disiplin belajar.

\section{PENUTUP}

\section{Kesimpulan}

Berdasarkan hasil analisis penelitian, dapat ditarik beberapa kesimpulan, yaitu;

1. Fasilitas belajar berkontribusi terhadap hasil belajar siswa. Kontribusi fasilitas belajar sebesar 0,191 atau 3,6 \% (kategori rendah). Kelengkapan fasilitas belajar berada dalam kategori sedang . ketersediaan fasilitas belajar yang paling tinggi adalah tersedianya penerangan yang cukup, sedangkan ketersediaan fasilitas belajar yang paling rendah adalah tidak memiliki perlengkapan belajar dan tidak tersedianya komputer. Dari data yang diperoleh menunjukkan bahwa fasilitas belajar secara efektif dapat meningkatkan hasil belajar siswa.

2. Disiplin belajar berkontribusi terhadap hasil belajar siswa. Pengaruh disiplin belaja sebesar 0,353 atau 12,5 $\%$ (kategori rendah). Tingkat disiplin belajar berada dalam kategori sedang. Tingkat disiplin belajar yang yang paling tinggi adalah menunjukkan sikap antusias dalam belajar, sedangkan tingkat disiplin belajar yang paling rendah adalah: pertama, melakukan hal-hal yang dilarang guru yaitu mencontek pada saat ulangan. Kedua, tidak dapat mengatasi godaan yang akan menunda waktu belajar yaitu godaan mematikan HP saat belajar dan godaan bermain dengan teman sebelum belajar. Dari data yang diperoleh menunjukkan bahwa disiplin belajar secara efektif dapat meningkatkan hasil belajar siswa.

3. Dari 256 siswa, 141 siswa atau 55,08 memiliki nilai rendah atau dibawah KKM. Dengan demikian kelengkapan fasilitas belajar dan tingkat disiplin belajar perlu ditingkatkan agar hasil belajar siswa dapat meningkat. Dari semua temuan dan hasil uji data penelitian, maka dapat disimpulkan bahwa seluruh hipotesis terbukti.

\section{DAFTAR PUSTAKA}

[1] Ahmadi, Abu. (2007). Sosiologi Pendidikan. Jakarta : PT Rineka Cipta.

[2] Al Muchtar, S. (2008). Strategi Pembelajaran Pendidikan IPS. Bandung: Sekolah Pascasarjana Universitas Pendidikan Indonesia.

[3] Arikunto, S. (2003). Dasar-dasar Evaluasi Pendidikan. Jakarta : Bumi Aksara

[4] Azwar, S. (2003). Penyusunan Skala Psikologi. Yogyakarta: Pustaka Pelajar. 
[5] Bahri, S . (2002). Rahasia Sukses Belajar.Jakarta : PT Rineka Cipta (2008). Rahasia Sukses Belajar.Jakarta : PT Rineka Cipta (2008). Psikologi Belajar.Jakarta : PT Rineka Cipta.

[6] Cahyono, H. (2009). Pengaruh Fasilitas Sekolah dan Motivasi Guru Terhadap Efektivitas Proses Belajar Mengajar di SMK Negeri I Garut. (Tesis). Bandung. Universitas Pendidikan Indonesia.

[7] Engkoswara. (1987). Dasar-Dasar Administrasi Pendidikan. Jakarta: Depdikbud

[8] Krismanto,H. (2007). Hubungan Kesiapan Fasilitas Belajar Layanan Pembelajaran dan Pengalaman Industri dengan Prestasi Belajar Mahasiswa di Politeknik TEDC Bandungn (Tesis). Bandung: Universitas Pendidikan Indonesia.

[9] Singarimbun,M.(2008). Metode Penelitian Survai. Jakarta: LP3ES.

[10] Siregar, E. (2010). Teori Belajar dan Pembelajaran. Bogor: Ghalia Indonesia.

[11] Sulistiyowati,S. (2008). Pengaruh Kedisiplinan Siswa dan Iklim SekolahTerhadap Prestasi Belajar Siswa Kelas II SMK Negeri 5 Semarang. www.wordpress.com, diakses tanggal 21 Januari 2010

[12] Suryabrata,S. (2010). Psikologi Pendidikan.Jakarta: PT Raja Grafindo Persada.

[13] Soewandi. (1993). Penyebab Gangguan Jiwa Manusia. Yogyakarta: Laporan Penelitian Dosen UGM (tidak diterbitkan)
[14] The Liang Gie. (2002). Cara Belajar Yang Efisien. Yogyakarta: Liberty.

[15] Tu`u, Tulus. (2004). Peran Disiplin Pada Perilaku dan Prestasi Siswa. Jakarta: Grasindo. 